\title{
Impact of Decentralization on Sustainable Development of the Newly Created Amalgamated Territorial Communities in the Regions of Ukraine
}

\author{
Ruslan Halhash ${ }^{1}$, Inna Semenenko ${ }^{1}$, Yana Bilous ${ }^{1}$, Iaroslav Burko ${ }^{1}$
}

\begin{abstract}
This article analyses the reform of decentralization in Ukraine and its role in the sustainable development of regions and newly created amalgamated territorial communities (ATCs). The reasons of the reform's implementation and the problems connected with the local management are specified. The study of foreign experience in reforming the administrative and territorial system has made it possible to draw conclusions about the effectiveness of decentralization as an instrument of change. With the beginning of the reform in Ukraine, the processes involving citizens' participation in managing sustainable development of the regions and the ATCs became more active. The analysis of financial decentralization in Ukraine showed the positive dynamics in local budgets' revenues. The development of a new governance model in a community implies involvement of the civil society in management and allocation of local budgets. The participatory budget is shown as a modern and effective instrument of local democracy. The advantages and the main effects of the participatory budgeting in ATCs for the purpose of their sustainable development were defined.
\end{abstract}

Keywords: decentralization, reform, sustainable development, region, amalgamated territorial community, participatory budget

\section{Introduction}

Sustainable development of Ukraine and its regions is possible only on the basis of successful decentralization reform. The decentralization reform consists of a system of organizational, administrative and financial measures that have significant impact on the development of newly created amalgamated territorial communities (ATCs). Particular attention in these processes should be paid to the relationship of organizational and financial changes. The successful coordination of these changes influences the balance of social, environmental and economic components of sustainable development and the achievement of the corresponding sustainable development goals at the level of individual regions.

The process of decentralization in the regions of Ukraine is complicated by the negative consequences of the military conflict. In particular, in Luhansk region, due to military actions and occupation of part of its territory, the existing environmental risks have significantly decreased, but the risks associated with the emergence of new environmental problems (mine threat, loss of control over technogeneous hazardous objects, increase of non-controlled use of resources, etc.) have increased. At the same time promotion of environment development is accompanied by decentralization processes and provision of certain autonomy in decision-making to ATCs. However, the 
expansion of ATCs' authorities requires efficient decentralized mechanisms to preserve the environment and solve environmental problems in such communities. To a certain degree, these mechanisms are incorporated into the updated Luhansk Region Development Strategy (The Lubansk. Region..., 2016), which also outlines the challenges that the newly created ATCs face. The document clearly states that it is extremely important to provide local self-government bodies in Luhansk region with greater autonomy.

The assignment of institutional support as a research direction in a separate section of The Concept of the Transition of Ukraine to Sustainable Development (Kontseptsiya perekhodu..., 2007) testifies the need for institutional support of sustainable development and its organization for the regions. In accordance with the concept the transition of the country to sustainable development foresaw certain steps. These steps included stabilization (creating preconditions for the transition); preparation (transformation of the economy of growth into the economy of development); transition (system transformations in the national economy); elaboration (completion of the transition of the country to the economy of sustainable development). All stages were to be carried out in accordance with the provisions of all constituents of the sustainable development concept and provided that the relevant institutional support was available and functioning, which became one of the points of the draft Concept on the transition of Ukraine to sustainable development. According to the concept the main role in the institutional support of sustainable development of Ukraine belonged to governmental institutions (legislative, executive, judicial bodies) and political parties (Kontseptsiya perekhodu..., 2007). However, such an approach was somewhat contradictory to the principles of the market system organization and could lead to bureaucratization and creation of inefficient institutions and organizations rather than to organization of effective institutional support. The Concept also paid attention to the intensification and strengthening of the role of civil society institutions at each of the stages of Ukraine's transition to sustainable development, as well as the establishment of an institutional system for managing rational use of natural resources, conservation and non-exhaustive use of biodiversity in the third transitional stage. Taking into account the decentralization reform, the institutional support of sustainable development of any region should entirely take place according to the "bottom-up" approach, and the governmental institutions should only create conditions for this.

Today, support of sustainable development of regions in Ukraine is taking place amid decentralization. Decentralization as a process of providing certain autonomy to ATCs in addressing local development issues should contribute to sustainable development of Ukrainian regions. Creation of ATCs should be voluntarily on the basis of certain economic incentives and understanding by the community's residents of the economic benefits of the amalgamation. However, nowadays the scientifically grounded organizational and economic mechanisms and specific application management tools for this are almost absent.

\section{Decentralization Reform and Sustainable Development}

The study of decentralization processes in Ukraine and the creation of 
organizational and economic management mechanisms in the newly created ATCs are conducted in various directions. During the years of local self-government in Ukraine, the main problems of its development are the lack of sufficient funding and the uncertainty in providing the authorities. On the whole, almost all researchers and practitioners agree that the effective implementation of national reforms at the local level requires appropriate organizational, methodological and technical support. Such support should be made for both: general issues of effective management and planning of the development of newly created ATCs, and specific issues, in particular, the use of ATC's resources. In our opinion, the implementation of the approaches identified in our previous studies of the strategic coordination of development of regional clusters (Halhash, 2017) and the institutional support of sustainable regional development (Buzko et al., 2017) can contribute to effective interaction between regional authorities and enterprises. But these results should be applied and implemented considering the impact of decentralization on sustainable development of newly created ATCs in the regions of Ukraine.

Support for sustainable development of regions in the conditions of decentralization is realized on the basis of forming additional funds from the rent and the environmental tax in the respective ATCs and the regional budget (Alexeev et al., 2016; Gunzenova, 2019; Kunce et al., 2008). However, the chosen version of the public administration system for Ukraine on the basis of granting broad powers to local self-government bodies in relation to territorial development requires the development of scientifically based organizational and economic mechanisms and applied management tools in the ATCs. Effective legal relations in the sphere of possession, use and disposal of local resources should create the economic basis for the development of ATCs. From the point of view of the most important issues of restoration of peace and public safety of the inhabitants of the ATCs, our research is aimed at the creation and use of additional funds from the rent and environmental tax in the ATCs as the basis of sustainable development, in particular, in the Luhansk region. Solving problems within this direction will definitely contribute both to solving the environmental problems of the ATCs and to obtain additional financial resources for their sustainable development.

Reforming the territorial organization of authorities on the principles of decentralization is one of the key areas of systemic social transformation in Ukraine. The development of the country is impossible without the development of its regions, and depends on how quickly and efficiently the processes of the establishment of ATCs take place, how effective and efficient management is at the regional and local levels. Understanding the importance and relevance of these problems, at the present stage of regional development, there is a question of the need to improve the theory and practice of organizational and economic support for the development of the ATCs. The new institutional transformations of regional and territorial authorities are conditioned by changes in the political system of society, the implementation of administrative and territorial, regional reforms, and require introduction of the improved regional governance mechanisms, definition of methods and areas of interregional cooperation and constructive partnership between the centre and the territories.

The process of decentralization in Ukraine began only in 2014 and today it is still not sufficiently examined and needs systematic elaboration and synthesis of the pillars of this 
process, as developed by the world community. The first attempts to move away from centralization in Ukraine were made in the early 90's. At that time, deregulation of the economy, in particular in the sphere of regulation of small and medium-sized businesses, was actively implemented. This was also due to the fact that governments in all developed countries regard this trend as the priority. Deregulation involves the disclosure of entrepreneurial potential in the country, promotes increased competition of employers in the labour market etc. However, deregulation is more concerned with the issues of business freedom and free economic relations. Instead, the issue of improving the institutional support for the development of the regions and the administrativeterritorial system almost has not been examined.

The model of regional government in Ukraine, which was formed in the Soviet times and inherited with independence, was based on the dominance of the governmental authorities in addressing the issues of local self-government and the development of the territories. Thus, the issue of decentralization has not been given much attention until the recent years, although the question of the necessity to construct the new model of territorial organization of authorities and the administrative-territorial system has repeatedly risen in the political and expert environment.

After proclamation of the independence of Ukraine on August 24, 1991, the question on the necessity to define and substantiate the optimal administrative-territorial system immediately came up. However, in practice, the Ukrainian state has faced the need to address a number of important political, economic, social, ethnic and other issues. The majority of the attempts to change the administrative system of the country stopped at the stage of conceptual rationale or draft laws. Instead, the problems associated with the imperfection of the administrative-territorial system and the management of the territories did not disappear, but over the years, increased. Particularly, they intensified at the lowest level - in villages, settlements and small cities, where local self-government is mainly unable to intensify economic activity and provide a favourable environment for people's livelihoods. In our opinion, the lack of rational zoning of territories and the balanced administrative-territorial system is connected with the lack of effective regional governance, which should be based on the use of improved organizational and economic mechanisms for the development of administrative-territorial units.

The presence of local self-government and the level of decentralization are the key features of a democratic state. The new administrative-territorial unit should become the basis for constructing a new territorial management model based on the principles of decentralization, subsidiarity, balance of national interests with the interests of the population in the regions and ATCs, the development of local self-government, the capacity and independence of ATCs to address the local issues.

\section{Foreign Experience of Decentralization}

Historically, the world has developed two basic models of public administration: European and Anglo-American. The European model combines local self-government and local authorities at the same territorial level but with different functions (De Vries, 2000; Krupina, 2010; Pavliuk et al., 2016). The Anglo-American model foresees that local self-government operates at all territorial levels below the state, the federation or an 
autonomous region. The central government does not intervene in the community managing local affairs. At the end of the XX century, the so-called newest model of public administration began to emerge. The main principles of the new model are the growing importance of civic initiatives, the impact of community residents on the activities of local self-government bodies; transfer of the rights to provide part of public services to non-governmental organizations and businesses; the right of the local government bodies to search for sources of funding for community development from non-governmental organizations and institutions (Balabayeva et al., 2016; De Lima et al., 2018).

The experience of the European countries shows that significant progress in the administrative-territorial system and local self-government reform was achieved only where the reformist innovations of the government considered the interests of local communities (Pavliuk et al., 2016; Krat et al., 2016; Shportiuk, 2011; Secco et at., 2017). Among the countries, which can share successful experience in decentralization processes are Sweden, France, Finland, Poland etc. Some of this experience can be used for Ukraine. Almost all the countries enforced this process to some extent. However, it is very important to take into account the interests of local citizens, because there is a risk of citizens losing confidence in the reform process and the political forces that have proclaimed these reforms.

In order for Ukraine to meet the EU requirements for local government, it is important to use the positive experience, as well as advisory assistance from the countries of the "new" Europe, who have been through this path recently and whose starting conditions for reform were similar to those of Ukrainian. Today, the UE support to Ukraine takes place simultaneously in several directions, but all these directions are more or less related to decentralization. Sweden supports Ukraine in matters of state budgeting and provision of administrative services, Estonia provides support for introduction of e-governance, Germany promotes energy efficiency, France contributes to public administration development, Spain deals with heat supply projects, Poland assists in improving administrative-territorial system etc. (Semenenko et al., 2019; Ministry of Regional Development, 2019). Another type of assistance to Ukraine in implementing strategic development programs is grant support from international funds and governments of various countries. There is already successful experience of international organizations activities aimed at promoting sustainable development of various problem territories in Ukraine (Semenenko et al., 2019). Thus, a lot of countries in the world and the EU in particular contribute to the democratic reform of decentralization and development of local self-government in Ukraine.

\section{Decentralization in Ukraine}

Today decentralization in Ukraine is the key socio-economic process. Relying on the positive experience of European countries, several directions of reforms are being implemented at once in Ukraine. These reforms include administrative-territorial, medical, pension, fiscal, educational, land, public administration etc. Organizational support for the decentralization process in Ukraine was accomplished through the adoption of a number of normative documents, the main of which are given in Table 1 . 
Table 1. Main legislative acts of Ukraine to support decentralization

\begin{tabular}{|l|l|l|}
\hline Date & Title & Content \\
\hline 2014 & $\begin{array}{l}\text { April, } \\
\text { Ministries of Ukraine "On } \\
\text { Approval of the Concept of } \\
\text { the Reform of Local Self- } \\
\text { Government and Territorial } \\
\text { Organization of Government } \\
\text { in Ukraine" }\end{array}$ & $\begin{array}{l}\text { and maintaining a healthy living environment for } \\
\text { fitizens, providing high-quality and accessible public } \\
\text { services, establishing institutions of direct democracy, } \\
\text { meeting the interests of citizens in all spheres of life, } \\
\text { harmonizing the interests of the government and } \\
\text { ATCs. }\end{array}$ \\
\hline $\begin{array}{l}\text { February } \\
5\end{array} 2015$ & $\begin{array}{l}\text { Law of Ukraine "On voluntary } \\
\text { amalgamation of territorial } \\
\text { communities" }\end{array}$ & $\begin{array}{l}\text { Regulation of relations that arise in the process of } \\
\text { voluntary amalgamation of territorial communities of } \\
\text { villages, settlements, cities, as well as voluntary } \\
\text { accession to the existing ATCs }\end{array}$ \\
\hline $\begin{array}{l}\text { April, } 8 \\
2015\end{array}$ & $\begin{array}{l}\text { The Resolution of the Cabinet } \\
\text { of Ministers of Ukraine "On } \\
\text { Approval of the Methodology } \\
\text { for the Formation of Capable } \\
\text { Territorial Communities" }\end{array}$ & $\begin{array}{l}\text { Definition of the mechanism and conditions for the } \\
\text { development of capable and efficient ATCs, the } \\
\text { procedure for the development and approval of the } \\
\text { perspective plan for establishing ATCs in Ukraine }\end{array}$ \\
\hline
\end{tabular}

Source: (Kontseptsiya reformuvannya..., 2014; Zakon Ukrayiny "Pro dobrovil'ne..., 2015; Pro zatverdz̧hennia..., 2015)

These normative documents formed the basis for the voluntary amalgamation of territorial communities in the regions of Ukraine. Thus, according to the Methodology in table 1, amalgamation of communities should take place solely according to the Perspective Plan, which is developed by the regional administrations according to the criteria specified in the Methodology. As a result, one can see the number and boundaries of potential ATCs in the perspective plan of each region (Ministry of Regional Development, 2019). The goal of decentralization of authorities in the regions is, first of all, establishment of the effective local governance structures that should promote sustainable development of ATCs through ensuring their ability to address local issues at the expense of own resources. This foresees provision of the ATCs with more resources and mobilizing their internal reserves.

It is possible to present the actual data on the first stage of decentralization, which reflects the dynamics of amalgamation of territorial communities in Ukraine. Before the decentralization reform started in 2014, there were 458 city councils, 783 town (selyshchni) councils, and 10,279 village (silski) councils in Ukraine. One village council may include several settlements (communities). On average one village council includes three village settlements, population of 370 people, and territory of 47 square $\mathrm{km}$. For comparison, in 1990, one village council had population of 1.9 thousand people. Thus, in the period from 1990 to 2014, the rural population has decreased significantly. At the beginning of 2015,9478 rural communities of Ukraine ( $92 \%$ of the total number of rural communities) had less than 3,000 residents, among them 4809 rural communities (47\%) had less than 1,000 residents (Parasiuk et al., 2016). Such fragmentation of the territory and the small population in the communities could not objectively ensure their economic 
development and provision of quality services to the residents. The mechanism of voluntary amalgamation of communities, the transfer of finance and authorities to the local level, should enable an increase in the standard of living of the population and promote sustainable development of the community.

Due to decentralization, in 2015, Ukraine managed to create 159 ATCs, and by the end of 2016 there were already 366 ATCs. Positive changes in new administrative-territorial units and the effective work of regional agencies have almost doubled the number of ATCs in 2017 to 665. During 2018, 117 ATCs more were created and their total number became 782. Due to the fact that in 2018 the pace of the ATCs creation was somewhat reduced, the Government of Ukraine decided to grant the status of ATC to the cities of regional significance (with adjacent communities). Thus, 2018 was marked by the opportunity to create an ATC with centres in the cities of regional significance without additional elections. 24 such communities were created for the past year. The possibility of accession to cities of regional significance gave a new impetus to the creation of capable and efficient communities. Before the reform started, there were 10952 territorial communities in Ukraine. Today 4142 of them (37.7\%) amalgamated and formed ATCs. By June 30, 2019, 877 ATCs were created in Ukraine (Figure 1).

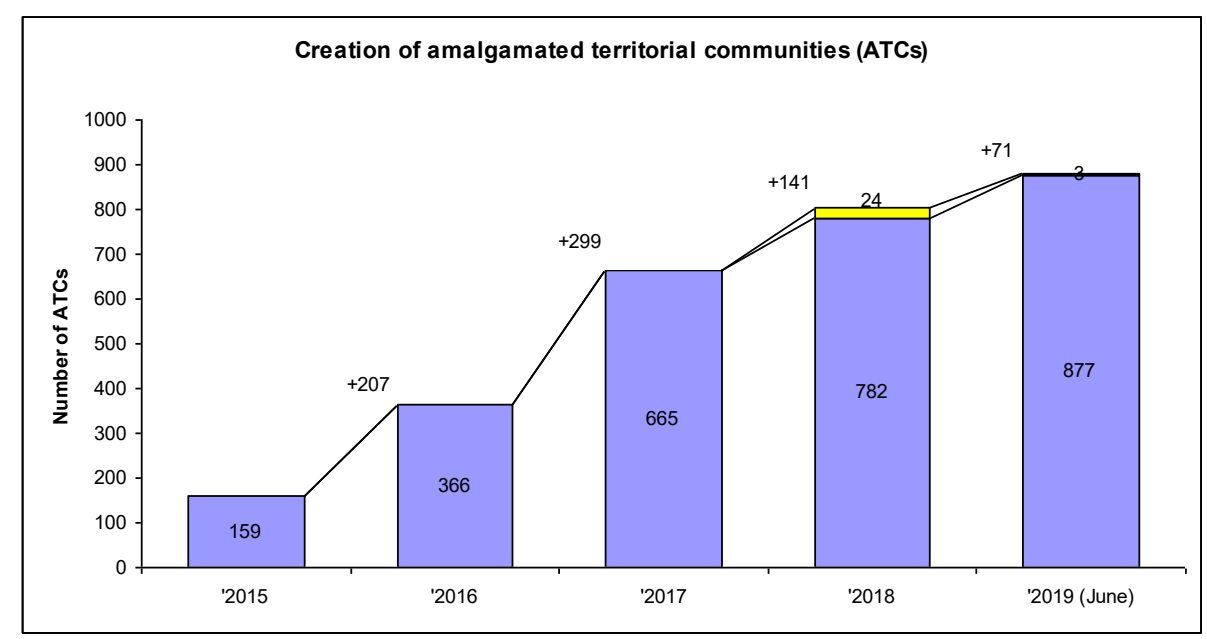

Figure 1. Dynamics of creation of ATCs in Ukraine

Source: (Ministry of Regional Development, 2019; Today 66 amalgamated..., 2019)

Decentralization reform became one of Ukraine's largest anti-corruption steps for all periods of its independence, since about 52\% of budget funds now remain at communities, which can use it for own development. The revenues of the local budgets during 2014-2019 have increased from 70.2 to 291.1 billion USD (Figure 2). With the adoption of the Law "On voluntary amalgamation of territorial communities" (Zakon Ukrayiny "Pro dobrovil'ne..., 2015), the ATCs have gained real instruments for development through amalgamation and transition to direct inter-budgetary relations with the government. Due to decentralization, most taxes remain in the community, including deductions from the national taxes and fees (personal income tax (which 
provides almost 57\% of budget revenues), excise, rent payments, etc.), revenues from local taxes and duties (single tax, property tax, land fees, tourist fees, etc.) and other revenues (fines, grants, etc.). Accordingly, the budgets of ATCs have increased from 5.0 bln USD in 2016 to 20.9 bln USD in 2018 (Figure 3) (Detsentralizatsiia ta reforma..., 2019).

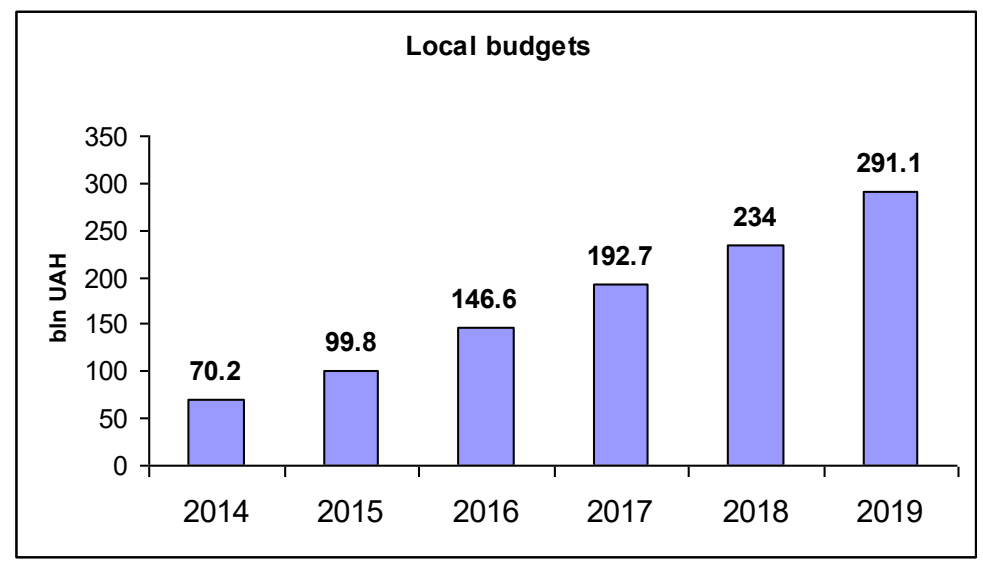

Figure 2. Revenues of local budgets during 2014-2019

Source: (Detsentralizatsiia ta reforma..., 2019)

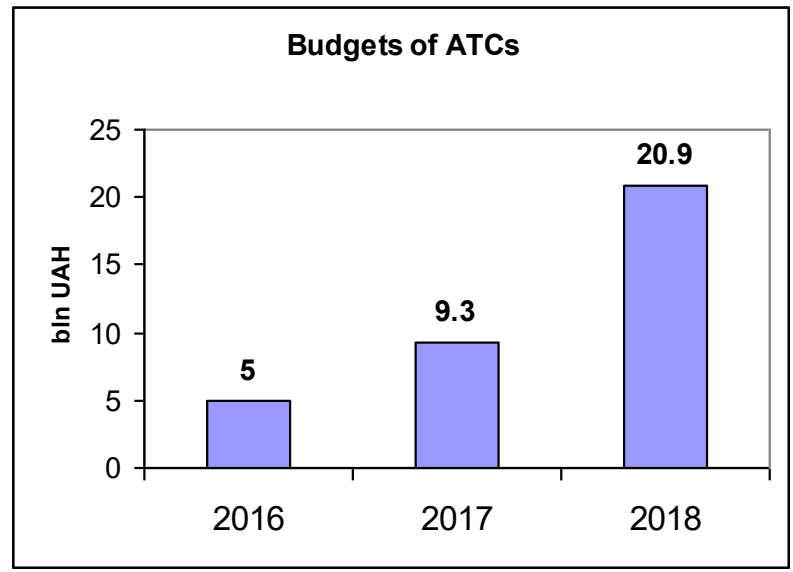

Figure 3. Revenues of ATCs' budgets during 2016-2019

Source: (Detsentralizatsiia ta reforma..., 2019)

The second part of the ATCs revenues consists of funds transferred directly from the state budget in the form of grants and subsidies. These funds go to the development of ATCs, funding education, medicine, and social protection. The share of funds transferred from the state budget varies in the range of $65-75 \%$ of total ATC revenues. The targeted financing of the development projects of the ATCs is also an effective mechanism. To ensure the development of ATCs, the Government has also introduced a mechanism for allocating funds from the State Fund for Regional Development (SFRD), 
which amounts to 1\% of the country's budget. Between 2015 and 2018 this Fund transferred more than 23 bln UAH to the budgets of ATCs, which provided implementation of more than 8,000 infrastructure projects. Information concerning state financial support for ATCs' development is presented in Table 2.

Table 2. State financial support for community development (UAH billions)

\begin{tabular}{|c|c|c|c|c|c|c|c|}
\hline Type of state support & 2014 & 2015 & 2016 & 2017 & 2018 & 2019 & Total \\
\hline Subvention for socio-economic development & 0.5 & 0.8 & 3.3 & 6.2 & 5 & 4.7 & 20.5 \\
\hline State Fund for Regional Development & & 2.9 & 3.0 & 3.5 & 6.0 & 7.7 & 23.1 \\
\hline Subvention to ATC infrastructure & & & 1.0 & 1.5 & 1.9 & 2.1 & 6.5 \\
\hline Funds for the construction of sports facilities & & & & 0.27 & 0.37 & 0.75 & 1.39 \\
\hline Subvention for the development of medicine in rural areas & & & & 4.0 & 5.0 & 5.0 & 14 \\
\hline Funds for support of sectoral regional policy & & & & 0.65 & 1.1 & 0.5 & 2.25 \\
\hline $\begin{array}{l}\text { Subvention for construction, reconstruction, repair and } \\
\text { maintenance of public roads of local importance }\end{array}$ & & & & & & 14.7 & 14.7 \\
\hline Total & 0.5 & 3.7 & 7.3 & 16.1 & 19.37 & 35.45 & 82.4 \\
\hline
\end{tabular}

Source: (Ministry of Regional Development, 2019)

The speed of projects submission to the SFRD and their quality have increased over the past two years, but still a significant part is being returned for revision. This happens due to the fact that most of the projects are aimed at repairing and "burrowing holes", but not the development of ATCs. The ATCs need to learn how to write quality projects in order to receive resources from the state budget and from international funds, and these projects should comply with the approved Development Strategies for newly created ATCs (Reforma detsentralizatsii..., 2019).

Despite the progress made in creating ATCs, there are still some problems with the organization of the territorial management system:

- The legislative regulation on local self-government as "the right guaranteed by the state and the real ability of a territorial community to address local issues" in practice becomes an uncertainty of community rights and fragmentation of authorities of local selfgovernment bodies. In turn, this leads to deepening the conflict of interests between local governments at different levels, as well as between self-government and state authorities at the level of regions and districts. Such contradictions complicate the establishment of effective interaction between local authorities and self-government and make it impossible to effectively manage the socio-economic development of the respective territory;

- there is no clear distinction between the authorities of local state administrations and local self-government bodies (according to the legislation, 76 authorities are duplicate), which impedes the construction of an effective mechanism for monitoring their implementation;

- lack of solidarity responsibility for the development of territories, low level of mutual trust between public organizations and authorities. Effective interaction between public authorities and civil society institutions is hampered by the lack of transparency in the activities of executive authorities and local self-government bodies, the complexity of performing public control over their activities, and the lack of involvement of members of territorial communities in the process of making managerial decisions. As a result, 
rational ideas of the active part of the public often not only do not reach the addressee, capable of their realization, but also run into opposition to local officials;

- unresolved issues of land ownership in ATCs. As a result, the authority of the village, town and city councils in control of land resources became restricted exclusively within the settlements, i.e. $12 \%$ of the territory of the state. Thus, local authorities are deprived of the opportunity to effectively plan the development of the territories, and the community, and to defend their interests in the decision-making process concerning the use of land resources (National Institute for Strategic Studies, 2015). Launched in 2018, the Land Reform is intended to resolve some of the issues related to the transfer of land to the newly established ATCs. However, for two years, no significant improvements have taken place, as the process is very slow. This is due to the imperfect mechanism of land transfer and the lack of a clear database of land, which requires a complete inventory.

The mentioned problems determine the critical importance of reforming the territorial organization of authorities, a part of which is the change of the administrative-territorial structure according to a democratic model of European countries. In general, the voluntary amalgamation of territorial communities during 2015-2019 is a significant positive result, which proves the effective changes of governance in Ukraine. Therefore, promoting further this process should be one of the main tasks for the local authorities and Ukrainian government. Throughout Ukraine, ATCs as efficient and capable local government bodies of the basic level should be established.

Significant progress has already been made towards the establishment of an effective regional governance and territorial organization of authorities to create and maintain a healthy living environment for citizens, providing high-quality and affordable public services, establishing institutions of direct democracy, harmonizing the interests of the state and the territorial communities, and promote sustainable development in ATCs. Today, almost $38 \%$ of the territory of Ukraine consists of ATCs, where about a quarter of Ukraine's population live. An independent resource base is created for local authorities: as a result of financial decentralization, the share of local budgets in the consolidated State Budget has increased to $52 \%$. The transfer of powers of executive authorities to local self-government bodies and their separation between levels and bodies on the principle of subsidiarity are taking place. A new network is being formed to provide high-quality and affordable local services: Administrative services centres are being set up, Hub-schools for thousands of children are being opened, a network of village clinics is being established. The rural communities that have joined the cities of oblast significance are able to develop, and can enjoy all the benefits and benefits of the city. The potential and financial reserve of the city allows to "overcome" the lack of budget of villages, as large cities have financial and organizational reserves that enable the city to solve problems in the village and promote their sustainable development. At the same time, agricultural land that joins the city together with the village is a valuable resource for the community, as there is the possibility of creating additional jobs through the development of entrepreneurship in agriculture. The city has a limited territory that did not allow activating these areas of development, but if there is development in the countryside, then the city will benefit from this. Rural territory becomes a point for attracting investments and community sustainable development. 
Thus, the new administrative-territorial unit should become the territorial basis for establishing the decentralized system of territorial management, which will ensure the most effective use of public resources, sustainable economic growth, increase of social standards of human life and preservation of the environment.

\section{The Role of the Participatory Budgeting in the Decentralization Reform in Ukraine}

The latest model of governance in the state envisages the influence of community residents on the activities of local self-government bodies, strengthening of community participation in solving local problems and increasing the importance of civic initiatives. In this context, issues of interaction of the civil society with local selfgovernment bodies become especially relevant. Increase of number of ATCs leads to increased community-government engagement (Edelenbos et al., 2009). Particular attention is paid to determining the role of government in the processes of community self-organization and in identifying the nature of the relationship between representatives of public institutions and the civil society (Nederhand et al 2016, 2019).

Sustainable development of ATCs significantly depends on the activity of local residents, their ability to learn and to use their rights, their willingness to participate in decisionmaking on the management of mutual resources, on initiatives for changes within the community that may be achieved through the effective use of modern instruments of democracy. In this context, the participatory budget serves as an important instrument not only for providing local democracy, but also as an instrument for sustainable development of the territories. The use of this instrument in the Ukrainian communities is possible due to the decentralization reform, which led to a significant increase in local budgets (Figures 2 and 3). The main idea of the participatory budget is the implementation of the process of interaction between the local authorities and its executive bodies with the local civil society. Such budgeting aims at involving community residents in the budgeting process by making decisions on the distribution of a certain part of the local budget through submission of project proposals and conduction of public voting for these projects, as well as ensuring the transparency of the activities and openness of the authorities (Bilous et al., 2018).

The participatory budget provides the following advantages for ATCs in Ukraine:

- The principles of the participatory budget require the allocation of the specific amount of money that will be used to implement community-based projects;

- The civil society is given the opportunity to participate in choosing the ways to develop its community, thus raising the level of social activity;

- Due to the need to submit projects by groups of citizens, the mobilization of residents to cooperate for the benefit of their community takes place;

- Mutual trust between the participants in the process of the participatory budgeting increases in terms of assigning tasks and responsibilities, establishing contacts and strengthening social relations;

- Promotion and increase of awareness imply the availability of basic knowledge of residents and executive authorities on using the local democracy tools and provide an 
opportunity to deepen this knowledge and acquire new competencies over time;

- The mechanism for implementing the participatory budget contributes to the emergence of the new public leaders and strengthening of the social sector;

- The design model of the participatory budget allows local governments to identify the bottlenecks and issues of concern to the public, which should be addressed in the first place;

- Transparency in the process of making managerial decisions is a prerequisite for the successful implementation of the participatory budget.

At the same time, the poor organization of the participatory budget implementation causes disputes and confrontation between the community and the authorities or between the authors of the projects, mainly in the initial steps of the participatory budget implementation.

It is possible to distinguish several effects of the participatory budget: organizational, economic, political, social, and environmental. The organizational and economic effects are complex in their essence, since they show an efficient combination of organization and management of local development by introducing participatory budgeting with the economic development of an administrative-territorial unit. So, it is important to introduce new approaches to managing the distribution of local finances, organizing and implementing the participatory budget process, and the professional use of this instrument to ensure the sustainable development of the territorial community and the region as a whole. The organizational component involves the choice or development of a model of the participatory budget and its implementation at all stages. In the organizational aspect, the local authorities should disseminate the information about the participatory processes so that citizens could participate in them. The economic efficiency foresees the rational approach to allocating budget funds directed towards sustainable development of any ATC by implementing participatory budget projects, which in turn should provide not only social, but economic and environmental development in a certain territory.

The significance of a social effect lies in the fact that, above all, there is an increase in social activity, cohesion, the growth of social satisfaction of community members etc. All this happens on the basis of their involvement in decision-making on the organization of participatory budgeting, distribution and use of the financial resources of the budget. The participatory budget contributes to promotion of social dialogue and cooperation between the different layers of population of the territorial community.

The political effect reveals itself in increase of trust to the local authorities and government as a whole, subject to the principle of transparency. The use of the latest local democracy tools, like the participatory budget, by the authorities speaks of an innovative approach to problem-solving, and thus demonstrates indifference of authorities to community sustainable development and future. The participatory budget envisages discussion and exchange of opinions, which allow the authorities to use the needs-based approach and to meet the expectations of the population in ATCs.

The environmental effect is realized through the civil society projects aimed at solving ecological problems, increase of environmental awareness and education, improvement of environment state at the specific territories. 
So far, it is difficult to estimate the influence of the participatory budget on the development of the regions of Ukraine, since today one can only talk about increasing the potential and investment attractiveness of communities through the implementation of the participatory budget projects. However, in the nearest future, the positive effect of using this innovative tool of local democracy will become visible in restored infrastructure, renovated communal facilities, educated community residents, increased social activity, improved efficiency of managing finances and community resources, and strengthened mutual trust between local governments and the civil society.

\section{Conclusion}

Sustainable development issues in the regions of Ukraine are closely linked to the process of decentralization, which involves coordination of the system of organizational, administrative and financial measures that significantly affect the sustainable development of the newly created ATCs. Decentralization in Ukraine has already shown the real positive results. Nevertheless, in order to minimize the problems in the management of territories, it is necessary to improve the legislation on transferring the authorities to the local level, as poor legislation impedes reform, slows sectoral decentralization processes, constrains the amalgamation of the territorial communities and sustainable development of the territories. For Ukraine, the experience of the EU countries in reforming the administrative and territorial system and local self-government is of great importance. It is necessary to follow the clear, legally defined criteria for establishment of new ATCs to avoid the creation of ineligible territorial units. The processes of reform and decentralization should be consistent and planned in order to prevent the reduction of the effectiveness of local development planning, the reduction of the level of coordination between different authorities, ineffective use of budget funds, etc. Consultative and financial assistance of the EU countries has a significant impact on the reform process in Ukraine. It is implemented in several directions, which include the issues of improving the administration and solution of communal services.

The process of voluntary amalgamation of territorial communities created the preconditions for the transformation of the territorial structure and the subregional level. The consequence is that at the district level, there operate the rayon state administration, district council, executive bodies of the ATCs with the authorities determined by the law, which in the overwhelming majority are duplicated. This situation requires the change in the system of government at the district level, redistribution and division of authorities and resources. Therefore, the next important step of further decentralization is the improvement of the territorial organization of authorities at the subregional level.

The decentralization reform involves transferring authorities and responsibilities to the local level. At the same time, it increases the requirements for the local government and encourages community members to engage with local government representatives. Thus, the issues of mutual management of the local resources, primarily financial ones, are actualized. The sustainable development of the region, including its territorial units, depend on the quality management of local funds. In our opinion, the problem of local budget management and the interaction between the executive authorities and the civil society can be solved by introduction of participatory budgeting in the ATCs. The 
participatory budget is a development tool that helps to unleash the potential of population, teach citizens to analyse their environment, to manage their resources, to make effective decisions and thus to contribute to sustainable development of their community.

At the same time, lack of practices in the field of effective interaction between the government and the civil society stipulates the search and the development of the new approaches to management in the regions. Also, the problem of the lack of methodological tools, which would become the basis for the successful implementation of the participatory budget in the territorial communities of Ukraine, remains a topical issue. In general, the process of amalgamation of territorial communities continues. The effective management of changes, which happen under the influence of decentralization processes, would engage citizens in the management of territories at the local level, use of the participatory budget as a modern instrument of representative democracy etc. to promote sustainable development of regions and ATCs in particular. It is very important at this stage to quickly analyse the problems and mistakes that arise during the reform process, to take them into account and correct them in the future. That is why further research requires the issue of promoting sustainable development of ATCs.

\section{References}

Alexeev, A., Good, H., Krutilla, K. (2016). Environmental taxation and the double dividend in decentralized jurisdictions. Ecological Economics, 122, 90-100. Doi: 10.1016/j.ecolecon.2015.12.004.

Balabayeva, Z., \& Ponomaryov, V. (2016) Theories of local self-government as a source of its future models searching. Actual problems of public administration, 1(65), 9-14.

Bilous, Y., \& Halhash, R. (2018). Analysis of international experience in implementing a participatory budget for territorial communities development in the regions of Ukraine. Visnyk of Volodymyr Dabl EUNU, 4(245), 128-133.

Buzko I., \& Semenenko I. (2017). Goal management of enterprises for sustainable development of a region: issues of institutional support. Visnyle of Volodymyr Dabl EUNU, 6(236), 37-44.

De Lima, A., \& Toni, F. (2018). The Energy Leviathan: or how US Shales and Brazil Biodiesel Governance Systems Fail to Promote Decentralization, Accountability, Equity, and Society Participation. European Journal of Sustainable Development, 7(3), 1-10. Doi: 10.14207/ejsd.2018.v7n3p1

De Vries, M. S. (2000), The rise and fall of decentralization: A comparative analysis of arguments and practices in European countries. European Journal of Political Research, 38, 193-224. doi:10.1111/1475-6765.00532

Detsentralizatsiia ta reforma mistsevoho samovriaduvannia: rezultaty sotsiolohichnoho doslidzhennia sered meshkantsiv terytorialnykh hromad, yaki proishly protses obiednannia u 2015-2016 rokakh. Analitychnyi zvit. (2019). Kyivskyi mizhnarodnyi instytut sotsiolobii. 214 p. Retrieved from: https://storage.decentralization.gov.ua/uploads/library/file/387/2019_03_otg_ukr.pdf.

Edelenbos, J., Klok, P., \& Van Tatenhove, J. (2009). The institutional embedding of interactive policy making. Insights from a comparative research based on eight interactive projects in the Netherlands. American Review of Public Administration, 39, 125-148.

Gunzenova, K. (2019). Ecological efficiency" as a value criterion of the sustainable development strategy. European Journal of Sustainable Development, 8(2), 217-224. Doi: 10.14207/ejsd.2019.v8n2p217.

Halhash R. (2017). Rehional'ni klastery pidpryyemstv: rozvytok ta stratehichna koordynatsiya. Retrieved from http://dspace.snu.edu.ua:8080/jspui/bitstream/123456789/2127/1/\%D0\%93\%D0\%B0\%D0\%BB $\% \mathrm{D} 0 \% \mathrm{~B} 3 \% \mathrm{D} 0 \% \mathrm{~B} 0 \% \mathrm{D} 1 \% 88$ \% $\% 0 \% \mathrm{DC} \% \mathrm{D} 0 \% \mathrm{BE} \% \mathrm{D} 0 \% \mathrm{BD} \% \mathrm{D} 0 \% \mathrm{BE} \% \mathrm{D} 0 \% \mathrm{~B} 3 \% \mathrm{D} 1 \% 80 \% \mathrm{D} 0$ $\% \mathrm{~B} 0 \% \mathrm{D} 1 \% 84$.pdf.

Kontseptsiya perekhodu Ukrayiny do staloho rozvytku. (2007). Visnyk of the National Academy of Sciences of Ukraine, 2, 15-44. 
Kontseptsiya reformuvannya mistsevoho samovryaduvannya ta terytorial'noyi orhanizatsiyi vlady v Ukrayini. (2014). Resolution of the Cabinet of Ministries of Ukraine dated April 1, 2014, No 333-p. Retrieved from https://zakon.rada.gov.ua/laws/show/333-2014- $\%$ D1\%80

Krat, M., \& Sofiy, O. (2016). The future of the districts of Ukraine: experience of Polish self-government at the powiat (county) level. Yevropeiskyi dialoh. Retrieved from: http://dialog.lviv.ua/en/maybutnyeukrayinskih-rayoniv-polskiy-dosvid-funktsionuvannya-mistsevogo-samovryaduvannya-na-rivnipovitiv/.

Krupina, N.A. (2010) Zarubizhnyi dosvid administratyvno-terytorialnoi reformy yak instrumentu udoskonalennia formuvannia finansovykh resursiv mistsevykh orhaniv vlady. Visnyk sotsialnoekonomichnykh doslid₹̧hen, 39, 263-268.

Kunce, M., \& Shogren, J. (2008). Efficient decentralized fiscal and environmental policy: A dual purpose Henry George tax. Ecological Economics, 65(3), 569-573. Doi: 10.1016/j.ecolecon.2007.08.004.

Ministry of Regional Development. (2019). Monitorynh protsesu detsentralizatsiyi vlady ta reformuvannya mistsevoho samovryaduvannya. Retrieved from https://storage.decentralization.gov.ua/uploads /library/file/414/10.06.2019.pdf

National Institute for Strategic Studies. (2015). Analitychna dopovid do Shchorichnoho Poslannia Prezydenta Ukrainy do Verkhovnoi Rady Ukrainy 'Pro vnutrishnie ta zovnishnie stanovyshche Ukrainy v 2015 rotsi'. Retrieved from: http://old2.niss.gov.ua/content/articles/files /POSLANNYA-2015_giper_new-4af35.pdf.

Nederhand, M., Bekkers, V., \& Voorberg, W. (2016). Self-organization and the Role of Government: How and why does self-organization evolve in the shadow of hierarchy? Public Management Review, 18(7), 1063-1084.

Nederhand, M., Klijn, E.-H., Van Der Steen, M., Van Twist, M. (2018). The governance of self-organization: Which governance strategy do policy officials and citizens prefer? Policy Sciences, 52, 233-253. Doi: 10.1007/s11077-018-9342-4.

Parasiuk, I., \& Teleshova, Y. (2016). Mistseve samovryaduvannya v Ukrayini ta sviti. Tsikavi fakty. Retrieved from http://radaprogram.org/sites/default/files/publications/broshura_misceve_samovryaduvannya_0.pdf

Pavliuk, A., Oliynyk, D., Batalov, O. (2016). Terytorialna hromada yak bazova nisha administratyvnoterytorialnoho ustroiu Ukrainy: problemy i perspektyvy reformuvannia: analitychna dopovid. Retrieved from: http://old2.niss.gov.ua/content/articles/files/AD-Teritor_alna-gromada-103fe.pdf.

Pro zatverdzhennia Metodyky formuvannia spromozhnykh terytorialnykh hromad. (2015). Resolution of the Cabinet of Ministries of Ukraine dated April 8, 2015. Retrieved from: http://zakon3.rada.gov.ua/laws/show/214-2015-\%D0\%BF.

Reforma detsentralizatsii - odna z kliuchovykh tem zasidannia predstavnytstv derzhav-uchasnyts OBSIe u Vidni. (2019). Ofis reform Kabinetu Ministriv Ukrainy. Retrieved from: https://rdo.in.ua/news/reforma-decentralizaciyi-odna-z-klyuchovyh-tem-zasidannyapredstavnyctv-derzhav-uchasnyc-obsye.

Secco, L., Favero, M., Masiero, M., \& Pettenella, D. (2017). Failures of political decentralization in promoting network governance in the forest sector: Observations from Italy. Land Use Policy 62: 79-100. Doi: /10.1016/j.landusepol.2016.11.013

Semenenko, I., Halhash, R., \& Ivchenko, Y. (2019). Role of International Organizations in Promoting Sustainable Development in Conflict-Affected Regions: Case of Luhansk Region in Ukraine. European Journal of Sustainable Development, 8(2), 21-34. Doi: 10.14207/ejsd.2019.v8n2p21.

Shportiuk, N. (2011). Administrative reform in Poland: experience for Ukraine. Deræhbavne upravlinnia ta mistseve samouriadwannia, 2(9), 48-52.

The Luhansk Region Development Strategy for the Period until 2020. (2016). Retrieved from https://www.undp.org/content/dam/ukraine/docs/Donbas/RPP/Luhansk-reg-devstrategy_ENG-14-06-2017.pdf.

Today 66 amalgamated hromadas hold their first elections, and $30 \mathrm{AHs}$ - additional ones. (2019). Official web-site. Decentralization. Retrieved from https://decentralization.gov.ua/en/news/11232.

Zakon Ukrayiny "Pro dobrovil'ne ob'yednannya terytorial'nykh hromad". (2015). Retrieved from: http://zakon3.rada.gov.ua/laws/show/157-19. 